\title{
Petisi Keumatan dan Kemasjidan
}

Shohibul Anshor Siregar

| Dalam bingkai globalisasi, warisan nilai diskriminatif kolonial, sekularisasi dan ekspresi-ekspresi negatif demokratisasi Indonesia, penguatan neoliberalisasi Negara saling menyokong dengan terjadinya ekspansi para kapitalis penyebab pertumbuhan (growth) ekslusif yang melahirkan kesenjangan yang amat parah | Diskusi konstitusi menguat, karena diyakini perkuatan neoliberalisasi Negara bersumber dari amandemen demi amandemen konstitusi | Kekuatan-kekuatan nalar penyeimbang dihadapkan dengan Negara seperti kejadian-kejadian penggusuran dan reklamasi di Jakarta, sedangkan mainstream media berdiri pada posisi membangun opini menstigmatisasi |

Kamis 22 September 2016 lalu, di Medan, dirumuskan sebuah dokumen yang diberi nama "Petisi Keumatan dan Kemasjidan". Petisi itu sendiri adalah hasil akhir dari konsultasi permasalahan aktual keumatan-kemasjidan dan konsolidasi gerakan pembelaan, yang difasilitasi oleh Lembaga Advokasi Umat Islam Majelis Ulama Indonesia (Ladui-MUI) Provinsi Sumatera Utara. Selain dihadiri para aktivis yang selama ini giat memberi advokasi dan pembelaan atas masjid-masjid yang menjadi korban gusuran di kota Medan, pertemuan itu juga mendapat masukan dari utusan organisasi-organisasi keumatan, termasuk tokoh-tokoh yang mewakili lembaga politik, pendidikan tinggi, dan lain-lain.

Di kota-kota besar seperti Medan, demikian salah satu bunyi petisi itu, memang belakangan marak kejadian yang memicu konflik, saat para pengembang berkehendak menguasai lahan yang di atasnya berdiri masjid, mushalla atau langgar. Sensitifnya, seluruh pengembang itu secara kategoris tidak ada yang berasal dari kalangan umat Islam. Lebih ironis lagi, semua terjadi dengan indikasi kolaborasi dengan institusiinstitusi Negara yang dipimpin oleh tokoh-tokoh yang secara kategoris beragama Islam.

Berbilangnya kasus serupa adalah pewartaan yang gamblang tentang kelemahan umat Islam saat ini. Ternyata mereka tidak memiliki administrasi kemasjidan yang cukup baik, dan itu terjadi seiring degradasi keberagamaan. Bagaimana sebuah masjid bisa seolah "tidak diperlukan lagi" begitu bertemu dengan kepentingan para pengembang hingga orang dengan begitu enteng menganggap tidak mengapa dirubuhkan? Di lapangan selalu ada reaksi yang berbeda-beda. Perbedaan itu bersumber dari kontroversi yang tak hanya karena penafsiran terhadap "perlakuan orang lain" terhadap masjid. Mereka tidak bersatu, kebanyakan justru karena dipecah oleh kekuatan korporasi.

Di bagian paling hulu memang salah satu kekhawatiran yang sangat mengancam saat ini ialah gejala kuatnya privatisasi agama. Sejalan dengan itu stigmatisasi terhadap umat Islam di NKRI mengarah kepada pemaksaan pemosisiannya menjadi sesuatu yang anachronistic (ketinggalan zaman) karena terus-menerus dihadapkan kepada pertempuran eksistensial bermotif politik yang dikendalikan oleh kekuatan dunia beserta agen-agennya di tanah air. 
Sepintas ini tak kelihatan murni pertarungan ideologi dan politik yang sudah berlangsung bahkan sebelum Indonesia berdiri, yakni saat hadirnya kekuatan-kekuatan asing yang sekaligus membonceng kepentingan-kepentingan tertentu. Ternyata sejarah selalu berulang, dan penguasaan ekonomi dan sumberdaya terus-menerus mendapat iklim kemunculan peran-peran kompradorisasi yang tak memperhitungkan kemaslahatan nasional. Di sini terasa sekali negara harus memperbaharui cara pandangnya terhadap agama, khususnya posisi umat Islam, dan makna pembangunan nasional berkeadilan. Inilah pangkal masalah yang diidentifikasi oleh "Petisi Keumatan dan Kemasjidan”.

Investasi adalah sesuatu yang sangat penting tak hanya bagi pemerintah. Korporasi hidup dan mengakumulasi kekayaan sedemikian rupa dari pola itu. Tetapi rasionalitas dan kalkulasi mereka (pemerintah dan korporasi) kerap berbeda dengan rasionalitas dan kalkulasi umat. Umat sama sekali tidak anti pembangunan dan kemajuan, malah nilai-nilai Islam ditawarkan secara bijak dan damai untuk memengaruhi jalannya pembangunan di segala bidang. Bagaimana agar konflik-konflik yang diakibatkan sengketa yang bertalian dengan masjid di antara korporasi dan umat tidak terjadi lagi pada depan? Ternyata hal itu sangat kompleks sebagaimana dapat dilihat dalam gambar di atas.

Dalam bingkai globalisasi, warisan nilai diskriminatif kolonial, sekularisasi dan ekspresiekspresi negatif demokratisasi Indonesia yang terus-menerus mencari bentuk dengan capaian amat minimum sebatas proseduralitas dan transaksi berbahaya, penguatan neoliberalisasi Negara saling menyokong dengan terjadinya ekspansi para kapitalis yang selama ini menjadi penyebab pertumbuhan (growth) ekslusif yang melahirkan kesenjangan yang amat parah.

Di mana-mana kini menguat diskusi tentang konstitusi, karena diyakini semua fenomena penelantaran sosial dan marginalisasi yang melahirkan kemiskinan struktural yang meluas di seluruh tanah air justru berawal dari faham perkuatan neoliberalisasi Negara yang bersumber dari amandemen demi amandemen konstitusi. Kekuatan-kekuatan nalar penyeimbang terpaksa berhadap-hadapan dengan Negara atau yang secara serampangan dimaknakan sebagai Negara. Untuk sekadar menyebut beberapa contoh aktual, perhatikanlah kejadian-kejadian penggusuran dan reklamasi yang dilakukan di Jakarta. Akhirnya kekuatan-kekuatan nasional yang menentang diposisikan sebagai anti pembangunan dan anti Negara, sedangkan mainstream media berdiri pada posisi membangun opini menstigmatisasi.

Kisah khas Sumatera pastilah menarik tak hanya untuk ulasan akademik, tetapi juga sebagai sorotan ideologis negarawan sejati. Lahan-lahan tertentu yang tadinya adalah eks HCU (Hak Guna Usaha) yang dikuasai oleh PTPN, kini sudah diambilalih segelintir pemodal/kapitalis secara monopolistik dengan menerabas hukum. Selain daerah tak memiliki rencana tata ruang yang baik dan menuntun, kekuatan politik dan ekonomi tertentu (minoritas) mengendalikan pemerintahan hingga soal tata ruang dan kontestasi penguasaan atas lahan selalu memicu konflik. Karena itu, perlu ada langkah hukum berupa gugatan untuk pembatalan penguasaan secara tidak adil (monopoli) tanah eks-HGU itu. 
Di Sarirejo, Medan, sekian dasawarsa rakyat berhadap-hadapan dengan Negara atau akhirnya secara simplistik dinyatakan sebagai Negara. Lucunya, Sarirejo sudah menjadi pangggung politik yang efektif bagi promosi orang-orang tertentu terutama dari kelembagaan politik yang berhajat ria mendapatkan sekeping kekuasaan politik. Mereka datang dengan niat setengah hati atau bahkan kurang dari itu, karena tanpa berbicara memaksa panglima tertinggi (presiden) tak akan ada kemajuan yang dapat dicapai.

Ironisnya, petak demi petak lahan di sekitar lokasi yang dipersengketakan itu beralih kepemilikan kepada pengembang dan elit ekonomi minoritas dan semua itu difasilitasi oleh Negara dengan kekuatan legitimasi hukum yang dimilikinya. Ini semua hanya mengikuti scenario perpindahan bandara Polonia ke Kualanamu yang dengan begitu sempurna mempercepat proses penguasaan lahan di kedua tempat (kawasan Polonia dan Kualanamu) oleh minoritas yang itu-itu juga, dan Negara bergembira ria menontonnya, mungkin oknum-oknum penguasanya sambil beroleh recehan.

Belum lama Sarirejo berduka. Bahwa saat hari-hari merayakan Ultah Kemerdekaan NKRI ke-71, mereka dihadapkan kepada kekuatan Negara yang memaksa mereka menerima kepentingan sepihak yang tak sesuai dengan fakta-fakta kebenaran yang mereka klaim. Betul semua harus dibawa ke wilayah pemutusan hukum yang seadiladilnya sesuai prinsip Negara hukum (rechtstaat), dan niat baik yang jelas mestinya harus muncul dari para pihak yang mencari panggung di wilayah konflik itu, agar mereka mampu menghadirkan hatinuraninya berhadapan dengan panglima tertinggi angkatan sebagai premus interpares.

Begitulah rakyat Sarirejo yang berdasarkan data kepemiluan memiliki pemilih tak kurang dari 40.000 merasa tak diindahkan oleh nawacita yang mestinya hadir sigap dan tegap di situ. Namun, ibarat luka masih berdarah, mereka dikhabari sebuah berita akan adanya mobilisasi 10.000 umat Budha yang akan mengadakan perhelatan di sana dalam waktu dekat dan mengusung tema perdamaian pula. Nalar kemanusiaan sudah tidak bekerja. Sensitifitas tak lagi mereka hitung, dan mereka melupakan sama sekali bahwa perasaan tergores umat Islam Indonesia masih belum sembuh akibat perlakuan jagal terhadap kaum Rohingya di Myanmar yang hingga kini tak mendapat perhatian internasional dan para pengungsinya yang kini ada di sekitar kota Medan masih belum mendapat kepastian nasib.

Kelihatannya para pemodal minoritas ini tak memiliki pertimbangan lain kecuali penguasaan sistem sumberdaya, dan jika itu akan menimbulkan riak-riak protes dan perlawanan pastilah akan dihadapkan kepada kekuatan resmi Negara. Bukankah kisah Si Pitung dan si Jiih telah berulang kembali dengan scenario yang sama? Belanda telah pergi, dan sebagai penjajah kita usir mereka dengan proklamasi 17 Agustus 1946 "Kami bangsa Indonesia, dengan ini menyatakan kemerdekaan Indonesia; hal-hal yang mengenai pemindahan kekuasaan dan lain-lain diselenggarakan dengan cara seksama dan dalam tempoh yang sesingkat-singkatnya”.

Kini, apalah bedanya dijajah Belanda 350 tahun jika Negara dengan penuh sukacita menonton bangsanya sendiri yang sudah dilemahkan berabad-abad oleh imperialisme kolonial justru (disuruh) berkompetisi dengan kekuatan global yang unggul dalam 
semua hal? Sumberdaya apa yang dimiliki oleh rakyat jelata untuk sekadar mempertahankan hidupnya sebagai manusia Indonesia dengan budaya dan citacitanya yang luhur? Inilah kekerasan struktural yang sengaja tak dibicarakan oleh Negara. Para negarawan yang memimpin nyata-nyata telah abai.

Perubahan peta demografis terutama di kota-kota besar seperti Medan, adalah salah satu ekspresi dari kekerasan struktural yang disebabkan penguasaan elit atas hampir seluruh sumberdaya di bawah legitimasi konstitusi Negara. Penguasaan kaum elit atas sumber daya ekonomi dan tanah secara monopolistik telah melahirkan kesenjangan dan ketidak-adilan yang bertentangan dengan sunnatullah dan filosofi bangsa ini (Pancasila).

Setiap orang sepatutnya tahu dan wajib memahami bahwa, meskipun terjadi perubahan demografis dan komposisi kependudukan, masjid yang tadinya memiliki jama'ah besar kini sudah tinggal sedikit berhubung penduduknya pindah ke tempat lain, tetapi masjid itu tidak serta-merta dapat dikatakan kosong. Tetapi dengan kemajuan dan mobilitas yang tinggi dalam masyarakat modern, saat ini kita dapat mengkategorikan tiga macam masjid secara adaptif. Pertama, masjid mukim yang difungsikan dan dimakmurkan oleh orang-orang yang tinggal berdekatan dengan lokasi masjid. Kedua, masjid yang mungkin dapat disebut masjid pekerja dalam arti dimakmurkan oleh orang-orang pekerja di sekitar lokasi masjid dan mungkin tak setiap waktu ada jama'ah. Ketiga, masjid musafir.

Dalam tradisi Islam, secara normatif status masjid adalah wakaf. Ketika sebuah masjid telah berdiri, pemilik sebenarnya adalah Allah, dan umat Islam sebagai perwakilan Allah di muka bumi wajib menjaga dan memakmurnya. Begitu berdiri, masjid tidak bisa berubah menjadi hak milik pribadi atau kelompok, bahkan bukan juga hak milik orang-orang yang telah mendirikannya. Urusannya tidak berhenti sampai di situ. Umat Islam sangat perlu memersatukan diri dan merapatkan barisan dalam menghadapi tantangan-tantangan ke depan terlebih dalam era globalisasi yang berlangsung, agar sebagai mayoritas dari segi jumlah (numerical majority) dapat berbanding lurus dengan peran sebagai mayoritas (technical majority) di NKRI.

Upaya memperbanyak ruang sinergitas di antara organisasi-organisasi keumatan dan pemerintah untuk pemberdayaan umat dalam kehidupan ekonomi, politik, budaya, ilmu pengetahuan dan teknologi, harus menemukan pola-pola baru yang sesuai dengan perkembangan zaman dan meninggalkan pola-pola yang dianut sejak zaman penjajahan. Disadari bahwa sebagai mayoritas di NKRI, di tengah kesenjangan ekonomi yang luar biasa parah, umat Islam dengan sendirinya kerap menjadi korban kekerasan struktural dalam posisi kemiskinan struktural yang sudah berusia lama. Kesenjangan yang terjadi di Indonesia sangat berbahaya, karena merupakan salah satu ancaman paling serius terhadap kondusivitas.

Tekanan internasional yang gencar dalam berbagai bentuk, antara lain melalui neoliberalisasi dan gencarnya global war on terrorism secara terus-menerus telah memojokkan umat Islam Indonesia ke posisi sulit. Kepadanya juga kerap disematkan stigma anti pluralitas sembari diposisikan sebagai umat yang suka kekerasan dan tindakan-tindakan diskriminatif lainnya. Padahal faktanya adalah bahwa perasaan 
keterampasan (relative deprivation) yang berakumulasi dalam kehidupan yang berkesenjangan telah menjadi realitas hidup (living reality) karena keadilan dalam segala bidang tidak ditegakkan, dan Negara nyata-nyata telah alpa menghadirkannya.

Solusi apa gerangan yang perlu diajukan? Para ilmuan sosial di Indonesia memang sudah lama lebih ingin memelajari rumus pertumbuhan (growth) dalam wacana pembangunan dan mencari argumen-argumen lokal untuk mendukung globalisasi yang mengagendakan hegemoni kuat oleh adi daya kepada Negara-negara miskin. Itu sudah saatnya ditinggalkan. Pemerintah perlu merujuk kepada sejarah, di antaranya saat Kabinet Juanda melaksanakan program Ekonomi Benteng yang kemudian diketahui program yang mirip juga diterapkan di Malaysia, yakni New Economic Policy (NEP).

Pada dasarnya kebijakan itu adalah bentuk affirmative action yang adil dan sangat antisipatif terhadap berbagai bentuk ancaman masa depan sebuah bangsa yang merdeka dan berdaulat. Selama kesenjangan menjadi karakteristik yang melekat pada Negara-bangsa, selama itu pula ancaman kondusivitas tidak akan dapat dieliminasi. Yakinlah, tax amnesty yang penuh kontroversi ini adalah tragedi besar hasil lanjutan dari kolonialisme, karena dana repatriasi yang diharapkan tak lain dari uang kekayaan Indonesia yang dibawa lari (ke luar negeri) dengan memanfaatkan kebobrokan sistem Negara.

Jika ekonomi Benteng berhasil tempohari, pelaku-pelaku utama perekonomian hanya akan membawa uang hasil usahanya dari satu lokasi ke lokasi lain di Nusantara, dan paling banter ia akan membangun di kampung halamannya sendiri di Pulau Jawa atau di Sumatera, di Kalimantan, di Sulawesi dan di Irian Barat yang terbelakang infrastruktur dan peradaban, untuk menghentikan kesenjangan struktural yang konon pernah menjadi alasan kuat untuk perang saudara (PRRI-Permesta).

Shohibul Anshor Siregar Naskah ini pertamakali diterbitkan oleh Harian Waspada, Medan, Senin 26 September 2016, hIm B7 